\title{
WHAT GLACIERS HAVE DONE FOR IOWA.
}

\author{
BY SAMUEL CALVIN.
}

Everybody knows in a general way that Iowa was once the abode of glaciers and presented an aspect as dreary and uninviting as the central portions of northern Greenland or the ice-locked continent of the-Antarctic. It may not, however, be so generally known that severe glacial conditions have recurred in Iowa more than once, and that, in some cases at. least; the interglacial-intervals were characterized by a mild climate and, in point of duration, were more than equal to all postglacial time. A consideration of Greenland and Antarctica, in their present condition of frigid desolation, would scarcely suggest that the action of glaciers could be, in any way, beneficent; but it needs only a comparison of preglacial, with postglacial Iowa to demonstrate the fact that glaciers and glacial action have contributed in a very large degree to the making of our magnificent State. What Iowa would have been, had it never suffered from the effects of the ponderous ice sheets that successively overflowed its surface, is illustrated, but not perfectly, in the Driftless area. Here we have an area that was not invaded by glaciers. This area lies mostly in Wisconsin, but its edges overlap southeastern Minnesota, northeastern Iowa and northwestern Illinois. In our own State Allamakee county and parts of Winneshiek, Fayette, Clayton, Dubuque and Jackson, belong to the Driftless area. Furthermore, the southern limits of glacial action are fairly well defined, coinciding in a general way with a line drawn from Jefferson City to St. Louis, and along the Ohio river from near its mouth to Pittsburgh. East of Pittsburgh the glacial boundary curves to the north and east and at last. conforms very nearly to the southern edge of Long Island. South of the line described there are further opportunities for comparing preglacial Iowa,-or rather what Iowa would have been without the modifications wrought by glaciers,-with the Iowa we know today. There is yet one other way 
of learning something about the surface of preglacial Iowa. During the last two decades numerons deep wells have been bored through the loose surface deposits and down into the underlying indurated rocks. The records of these wells show that the rock surface is very uneven. Before the glacial drift, which now mantles nearly the whole of Iowa, was deposited, the surface had been carved into an intricate system of hills and valleys. There were narrow gorges bundreds of feet in depth, and there were rugged rocky cliffs and isolated buttes. corresponding in height to the depth of the valleys.

If the eroded rock surface had not been covered up and protected by the mantle of glacial detritus, the angular, jagged topography indicated by well records as characterizing. preglacial Iowa, would have been toned and softened, to some extent, by erosion and atmospheric waste. So far, therefore, as topography is concerned, the Driftless area and other nonglaciated portions of the country give a more correct notion of what Iowa would have been if the great ice sheets had not. worked their beneficent effects upon its surface.

The Driftless area differs from the drift-covered portions of Iowa in a number of important particulars. For present. purposes, however, these differences may conveniently be reduced to two classes: First, differences in topography, and, second, differences in the superficial materials or soils.

To a person passing from the drift-covered, to the driftless part of the State, the topography presents a series of surprises. The gentle undulations of the drift give place to sharp contours and high reliefs. The topography is of the most pronounced erosional type. The principal drainge streams flow in valleys that, measured from the summits of the divides, are six hundred feet or more in depth. The Oneota or Upper Iowa river, in Allamakee county, for exam. ple, flows between picturesque cliffs that rise almost vertically to a height of from three hundred to four hundred feet, while from the summit of the cliffs the land rises gradually to the crest of the divides, three, four, or five miles back from the 
stream. Tributary streams cut the lateral slopes and canyon walls at intervals. These again have tributaries of the second order. Each affluent indeed branches and re-branches until the whole surface of the drainage slopes is occupied by a palmate system of sharp erosion channels separated by rounded ridges. In such a region a quarter section of level land would be in the nature of a curiosity. The striight, section-line roads that divide the drift-covered parts of the State into squares as regular as a checker board, are altogether unknown; for highways must, perforce, go where they can, and in the Driftless area they wind along the summits of ridges or pursue an even more tortuous course along the stream valleys. In passing from valley to divide the grades are steep and long; and always, no matter what the direction or purpose of the traveler, the way is sinuous, and the journey is much longer than would be necessary if it were possible to follow straight lines.

Railroad building in such a country is almost out of the question. At all events it is attended with difficulties that would scarcely be appreciated by the residents of the driftcovered portions of the State. For example, the short piece of road between Waukon Junction and Waukon pursues a tortuous journey of thirty-three miles, and yet the two points, measured on an air line, are only about sixteen miles apart. In the thirty-three miles of distance the grade rises nearly six hundred feet, while curves, numerous" and sharp, offer further obstacles to successful operation. The road in question follows the valley of Paint creek, and the trains winding back and forth on the sinuous track grind around the sharp curves with creakings and groanings unutterable. This is a fair example of railroading in the Driftless area, a fair example of conditions that would have been met throughout the whole State of Iowa had it not been for the leveling effects of glaciers. Compare this picture with that presented by railways in the counties west of Howard, Chickasaw and Fayette, where the lines are laid out on straightaway courses, 
across valley and watershed, with scarce perceptible grade, for scores of miles at a stretch. For the matchless facilities with which the highways of transportation, between different portions of our State and neighboring States, are established and maintained, we are indebted, to an extent difficult to appreciate, to the beneficent action of glaciers.

In the matter of soils our debt to glacial action is even greater than in the matter of topography. In a non-glaciated Iowa we might have moved about from point to point, though as compared with present conditions it would have involved great expense, great loss of time, and much inconvenience. But a non-glaciated Towa could never have taken rank as a great agricultural State. In an area that has received no glacial tribute the soils are, in general, the result of decay of rocks in place. If, as in the case of Iowa, the area has but recently been elevated from three hundred to six or eight hundred feet above base level, the drainage streams flow in deep valleys. The sides of the valleys rise at a high angle. As fast ns the soil is formed it is washed from the steep slopes. Over a large percentage of the surface the rocks are bare, while areas that are not completely denuded have soils too thin for purposes of successful agriculture. Furthermore even where such residual soils as are possible to Driftless regions accumulate to a moderate depth, they are found to vary with the nature of the underlying rocks from which they are derived; they are completely oxidized and thoronghly lenched of all soluble constituents; they are difficult of cultivation, and crops can only be produced at the expense of much labor and by the liberal use of fertilizers. Exceptions to this general statement are found in narrow belts of rich alluvial soils along the stream valleys; but soils of uniform excellence, spreading between the two great rivers, and from northern to southern boundary, would have been impossible in a non-glacial Iowa.

The conversion of a deeply trenched and eroded surface into a gently undulating plain, upon which wagon roads and 
railways, facilinting social and commercial intercourse, may be constructed with a minimum of labor and expense, is a service of immeasurable value; and yet this is one of the least of the beneficent effects of glacial action in Iowa. The soils of Iowa have a value equal to all the gold and silver mines of the world combined. In fact it is difficult to find sources of wealth with which our soils may properly be compared. And for all this rich heritage of soils we are indebted to great rivers of ice that overflowed Iowa from the north and northwest. The glaciers, in their long journey, ground up the rocks over which they moved and mingled the fresh rock flour derived from granites and other crystalline rocks of British America and northern Minnesota with pulverized limestones and shales of more southern regions, and used these rich materials in covering up the bald rocks and leveling the irregular surface of preglacial Iowa. The materials are, in places, hundreds of feet in depth. They are not oxidized or leached, but retain the carbonates and other soluble constituents that contribute so largely to the growth of plants. The physical condition of the materials is ideal, rendering the soil porous, facilitating the distribution of moisture, and offering unmatched opportunities for the employment of improved machinery in all the processes connected with cultivation. Even the Driftless area received great benefit from the action of glaciers, for, although the area was not invaded by ice, it was yet to a large extent covered by a peculiar deposit called loess which is genetically connected with one of the later sheets of drift. The loess is a porous clay rich in carbonate of lime. Throughout the driftless area it has covered up many spots that would otherwise have been bare rocks. It covered the stiff, intractable residual clays that would otherwise have been the only soils of the regions. In itself it constitutes a soil of great fertility. Every part of Iowa is debtor in some way or other to the great ice sheets of the glacial period. 
Copyright of Annals of Iowa is the property of State of Iowa, by \& through the State Historical Society of Iowa and its content may not be copied or emailed to multiple sites or posted to a listserv without the copyright holder's express written permission. However, users may print, download, or email articles for individual use. 